\title{
Imbibition temperature affects on seedling vigor: In crops and shrubs
}

\author{
D. TERRANCE BOOTH AND YUGUANG BAI
}

Authors are rangeland scientist, USDA-ARS, High Plains Grassl. Res. Sta., 8408 Hildreth Road, Cheyenne, Wyo. (email: tbooth@lamar.colostate.edu), and range ecologist, Agr. and Agri-Food Canada, Kamloops Range Res. Unit, 3015 Ord Road, Kamloops, BC V2B 8A9, Canada (email:baiy@em.agr.ca).

\begin{abstract}
Imbibition at cold temperatures reduces seedling vigor of some species, but is beneficial to others. We used 3 rangeland shrubs and 8 agronomic crop species to test for a general relationship between imbibition temperature $\left(5\right.$ to $\left.30^{\circ} \mathrm{C}\right)$ and seedling vigor measured as post-germination growth; and to test for an effect of imbibition temperature on seed water uptake and dry weight loss during imbibition. Imbibition temperatures between 5 and $15^{\circ} \mathrm{C}$ were correlated with greater seedling length of the shrubs while most crops were favored by imbibition temperatures between 20 and $30^{\circ} \mathrm{C}$. Winter wheat (Triticum aestivum $\mathbf{L}$.) response to imbibition temperature was similar to that of the shrubs. Generally, shrubs had lower post-germination growth than crops, and during imbibition most crop seeds lost less weight than shrub seeds. Winter wheat had high weight loss as well as high seedling vigor. Seed water content generally increased with increasing imbibition temperature; however, winter wheat, kochia (Kochia prostrata (L.) Schrad.), and big sagebrush (Artemisia tridentata Nutt.) had significantly less water when imbibed at $30^{\circ} \mathrm{C}$ than when imbibed at lower temperatures. The differences due to temperature suggest the relationship between imbibition temperature and seedling vigor is a general phenomenon related to the physiology of water uptake and to seed respiration (as indicated by weight loss). Therefore, we recommend that optimum imbibition temperatures be defined by species and incorporated into seed-testing guidelines. This appears particularly important for species that do not have a long history of cultivation and whose response to temperature may differ significantly from that of crops.
\end{abstract}

Key Words: imbibition damage, germination, post-germination growth, imbibition weight loss, seed testing

Seed (or seedling) vigor is a condition of active good health that permits germination and early growth to proceed rapidly and completely (Justice and Bass 1978). Vigor, measured as post-germination growth, is generally reduced by imbibition at cold temperatures for common agronomic species (Vertucci

Authors thank Dr. N.L. Shaw for supplying hopsage seeds, L.W. Griffith for technical assistance, and Drs. M.A. Cohn, M.B. McDonald and E.E. Roos for reviewing this manuscript. Mention of trade or company names is for information only and does not imply an endorsement.

Manuscript accepted 19 Oct. 1998

\section{Resumen}

La imbibición a bajas temperaturas reduce el vigor de las plántulas de algunas especies y es benéfica para otras. Utilizamos 3 arbustos de pastizal y 8 especies cultivadas para probar una relación general entre la temperatura de imbibición $\left(5\right.$ a $\left.30^{\circ} \mathrm{C}\right)$ y el vigor de la plántula (medido como crecimiento post-germinación) y para probar el efecto de la temperatura de imbibición en la absorción de agua de la semilla y perdida de peso seco durante la imbibición. Las temperaturas de imbibición entre 5 y $15^{\circ} \mathrm{C}$ se correlacionaron con una mayor longitud de la plántula de los arbustos mientras que la mayoría de los cultivos respondieron mejor a las temperaturas de imbibición entre 20 y $30^{\circ} \mathrm{C}$. La respuesta del trigo invernal (Triticum aestivum $\mathbf{L}$.) a la temperatura de imbibición fue similar a la de los arbustos. Generalmente los arbustos tienen menor crecimiento post-germinación que las especies cultivadas y durante la imbibición la mayoría de las semillas de los cultivos pierden menos peso que las semillas de arbustos. El trigo invernal tuvo una alta perdida de peso y un vigor de plántula alto. El contenido de agua de la semilla generalmente se incrementa al incrementar la temperatura de imbibición, sin embargo, el trigo invernal, kochia (Kochia postrata (L.) Schrad), y big sagebrush (Artemisa tridentata Nutt.) tuvieron un contenido de agua significativamente menor cuando se imbibieron a $30^{\circ} \mathrm{C}$ que cuando se imbibieron a temperaturas más bajas. Las diferencias debidas a la temperatura sugieren que la relación entre la temperatura de imbibición y el vigor de plántula es un fenómeno general relacionado a la fisiología de absorción de agua y la respiración de la semilla (Tal como lo indica la perdida de peso). Por lo tanto, recomendamos que la temperatura óptima de imbibición se sea definida por especie e incorporada en las guías de pruebas de semilla. Esto parece ser particularmente importante para especies que no tienen un largo historial de cultivo y cuya respuesta a la temperatura puede deferir significativamente de otros cultivos.

1989, Bradford 1995). Low imbibition temperature reduces seedling vigor in lima bean (Phaseolus lunatus L.) (Woodstock and Pollock 1965, Pollock 1969), bush bean (Phaseolus vulgaris L.) (Pollock et al. 1969, Roos et al. 1976), cucumber (Cucumis sativus L.) (Segeta and Tronickova 1966, Jennings and Saltveit 1994), pea (Pisum sativum L.) (Highkin and Lang 1966), and many other important crops with tropical or subtropical origins (Lyons 1973). Imbibition at $5^{\circ} \mathrm{C}$ for 30 
minutes reduced oxygen uptake of lima bean seedling axes by 20 to $40 \%$ relative to imbibition at $25^{\circ} \mathrm{C}$ (Woodstock and Pollock 1965), with injury at $5^{\circ} \mathrm{C}$ being related to the moisture content of the seed (Pollock 1969). By contrast, some seeds such as spiny hopsage (Grayia spinosa (Hook.) Moq.) (Smith 1974, Shaw et al. 1994), kochia (Kochia prostrata (L.) Schrad.) (Haferkamp et al. 1990), winterfat (Eurotia lantata (Pursh) Moq.) (Booth 1992), and cold resistant maize (Zea mays L.) cultivars (van de Venter and Grobbelaar 1985), can have greater seedling vigor after cold ( 0 to $\left.10^{\circ} \mathrm{C}\right)$, compared to warm $\left(>15^{\circ} \mathrm{C}\right)$, imbibition temperatures. To determine if there is a general correlation between imbibition temperature and seedling vigor, we tested 3 rangeland shrubs and 8 agronomic crop species and measured the effects of imbibition temperature on post-germination growth and how growth is related to seed water uptake and weight loss during imbibition.

\section{Materials and Methods}

\section{Seed Sources}

Seeds were obtained from commercial sources except for spiny hopsage and kochia, which were collected from Oregon and Utah, respectively (Table 1). Seed weights ranged from $0.028 \mathrm{~g}$ per 100 seeds for spiny hopsage to 32.55 g per 100 seeds for bush bean. After purchasing or harvesting, seeds were stored at room temperature. Seed weight on a dry weight basis was determined at the beginning of each study.

\section{Water Uptake and Weight Loss of Seed/Seedlings During Imbibition at VariousTemperatures}

Seeds of each species were divided into 5 groups or replications. The number of seeds per group ranged from 10 (pea, bean, etc.) to 140 (hopsage), depending on the number of seeds needed to exceed a minimum group weight of $0.05 \mathrm{~g}(0.04 \mathrm{~g}$ for hopsage due to our limited supply). The seed groups of each species were weighed to $0.01 \mathrm{mg}$, then dried at $35^{\circ} \mathrm{C}$ for 7 days. This procedure was designed to obtain a stable "dry" weight without damaging the embryos (Booth 1992). Seeds were humidified by placing them above distilled water in a closed container at $2{ }^{\circ} \mathrm{C}$ until seed moisture content exceeded $10 \%$ as determined by daily weighing. This was done to standardize seed moisture and reduce the chance of imbibitional injury (Pollock 1969, Vertucci and Leopold 1984). Humidified seeds were mounted on slant boards (Jones and Cobb 1963), placed in closed $25 \times 40 \times 21 \mathrm{~cm}$ plastic boxes, and then imbibed for 4 days in incubators at $5,10,15,20,25$, or $30^{\circ} \mathrm{C}$. After imbibition, seeds/seedlings were dried as described above and the percent weight loss during the 4-day imbibition was calculated on a dry weight basis. The experimental design was a randomized complete block design (RCBD). Data $(n=5)$ were analyzed separately for each species using analysis of variance (ANOVA) and means were compared with the Least Significant Difference (LSD) where there was a significant $\mathrm{F}$ statistic for treatment effects (Snedecor and Cochran 1980). Temperature is a continuous variable; however, some seed responses suggest biological thresholds that produce discrete responses which are better analyzed by ANOVA and LSD.

\section{Seed Germination and Seedling Vigor in Relation to Imbibition Temperature}

Twenty humidified seeds were mounted on slant boards, placed in closed plastic boxes, and then imbibed for 4 days in incubators at 5, 10, 15, 20, 25, or $30^{\circ} \mathrm{C}$. They were then incubated at constant or alternating temperatures in darkness for 7 days for crops, or 14 days for shrubs, as recommended by the Association of Official Seed Analysts (AOSA 1988) or Schopmeyer (1974). The incubation conditions were $20 / 30^{\circ} \mathrm{C}$ under 16/8 hours light/darkness for cucumber, sunflower (Helianthus annuus L.), tomato (Lycopersicon pimpinellifolium) Mill.), bush bean and hopsage;

Table 1. Description of seed sources and other characteristics for the 3 shrubs and 8 crop species examined in this study.

\begin{tabular}{|c|c|c|c|}
\hline Species and cultivar & Age of seed (years) & Source & Seed weight (mean \pm SE/100 seeds) \\
\hline & & & $-------(g)----\cdots$ \\
\hline \multicolumn{4}{|l|}{ Spiny hopsage } \\
\hline (Grayia spinosa (Hook.) Moq.) & 4 & Malheur, Ore. & $0.028 \pm 0.002$ \\
\hline Kochia & & & \\
\hline (Kochia prostrata (L.) Schrad. & 3 & Sanpete, Ut. & $0.106 \pm 0.002$ \\
\hline Big sagebrush & & & \\
\hline (Artemisia tridentata Nutt.) & 1 & Wind River Seed Co., Manderson, Wyo. & $0.046 \pm 0.001$ \\
\hline $\begin{array}{l}\text { Cucumber, Straight Eight } \\
\text { (Cucumis sativus L.) }\end{array}$ & 1 & Gurney’s Seed Co., Yankton, S. Dak. & $2.004 \pm 0.036$ \\
\hline $\begin{array}{l}\text { Sunflower, Black Stripe } \\
\text { (Helianthus annuus L.) }\end{array}$ & 1 & Gurney's Seed Co., Yankton, S.Dak. & $8.418 \pm 0.107$ \\
\hline $\begin{array}{l}\text { Tomato, Delicious } \\
\text { (Lycopersicon pimpinellifolium Mill.) }\end{array}$ & 1 & Gurney's Seed Co., Yankton, S.Dak. & $0.247 \pm 0.001$ \\
\hline $\begin{array}{l}\text { Bush Bean, Top Crop } \\
\quad(\text { Phaseolus vulgaris L.) }\end{array}$ & 1 & Gurney's Seed Co., Yankton, S.Dak. & \\
\hline $\begin{array}{l}\text { Pea, Alaska } \\
\quad \text { (Pisum sativum L.) }\end{array}$ & 3 & Gurney's Seed Co., Yankton, S.Dak. & $9.310 \pm 0.321$ \\
\hline $\begin{array}{l}\text { Radish, Mr. Big } \\
\quad \text { (Raphanus sativus L.) }\end{array}$ & 4 & Gurney's Seed Co., Yankton, S.Dak & $1.030 \pm 0.017$ \\
\hline $\begin{array}{l}\text { Spinach, Bloomsdale Long Standing } \\
\text { (Spinacia oleracea L.) }\end{array}$ & 1 & Gurney's Seed Co., Yankton, S.Dak. & $1.077 \pm 0.018$ \\
\hline $\begin{array}{l}\text { Winter Wheat, Buckskin } \\
\text { (Triticum aestivum L.) }\end{array}$ & 2 & Wyo. Certified Seed, Univ. Wyo., Laramie & $3.477 \pm 0.006$ \\
\hline
\end{tabular}


Table 2. Seed/Seedling water content on dry weight basis of 3 shrub and 8 crop species after 4 days of imbibition at various temperatures.

\begin{tabular}{|c|c|c|c|c|c|c|}
\hline \multirow[b]{2}{*}{ Species } & \multicolumn{5}{|c|}{ Imbibition temperature $\left({ }^{\circ} \mathrm{C}\right)$} & \multirow[b]{2}{*}{30} \\
\hline & 5 & 10 & 15 & 20 & 25 & \\
\hline & ---- & $-\cdots$ & $-\%--$ & $--\cdot-\cdot$ & $-\ldots$ & \\
\hline Grayia spinosa & $132 \mathrm{a}^{1}$ & $165 \mathrm{a}$ & $181 \mathrm{a}$ & $180 \mathrm{a}$ & $210 \mathrm{a}$ & $201 \mathrm{a}$ \\
\hline Kochia prostrata & $190 \mathrm{c}$ & $186 \mathrm{c}$ & $400 \mathrm{a}$ & $335 \mathrm{ab}$ & $275 \mathrm{~b}$ & $182 \mathrm{c}$ \\
\hline Artemisia tridentata & $156 \mathrm{~d}$ & $213 \mathrm{~cd}$ & $345 \mathrm{ab}$ & $373 \mathrm{a}$ & $282 \mathrm{abc}$ & $240 \mathrm{bcd}$ \\
\hline Cucumis sativus & $61 \mathrm{~d}$ & $65 \mathrm{~d}$ & $64 \mathrm{~d}$ & $182 \mathrm{c}$ & $494 \mathrm{~b}$ & $726 \mathrm{a}$ \\
\hline Helianthus annuus & 59 e & 80 e & $125 \mathrm{~d}$ & $202 \mathrm{c}$ & 314 & $423 \mathrm{a}$ \\
\hline Lycopersicon pimpinellifolium & $94 \mathrm{~d}$ & $91 \mathrm{~d}$ & $96 \mathrm{~d}$ & $128 \mathrm{c}$ & $235 \mathrm{~b}$ & $298 \mathrm{a}$ \\
\hline Phaseolus vulgaris & $88 \mathrm{e}$ & $98 \mathrm{de}$ & $105 \mathrm{~d}$ & $133 \mathrm{c}$ & $194 \mathrm{~b}$ & $225 \mathrm{a}$ \\
\hline Pisum sativum & $102 \mathrm{~d}$ & $110 \mathrm{~d}$ & $137 \mathrm{c}$ & $197 \mathrm{~b}$ & $219 \mathrm{a}$ & $215 \mathrm{a}$ \\
\hline Raphanus sativus & $85 \mathrm{~d}$ & $160 \mathrm{~d}$ & $376 \mathrm{c}$ & $1105 \mathrm{~b}$ & $1512 \mathrm{a}$ & $1478 \mathrm{a}$ \\
\hline Spinacia oleracea & $78 \mathrm{c}$ & $83 \mathrm{bc}$ & $87 \mathrm{bc}$ & $99 \mathrm{~b}$ & $121 \mathrm{a}$ & $93 \mathrm{bc}$ \\
\hline Triticum aestivum & $76 \mathrm{~d}$ & $216 \mathrm{c}$ & $355 \mathrm{a}$ & $192 \mathrm{c}$ & $273 b$ & $214 \mathrm{c}$ \\
\hline
\end{tabular}

${ }_{1}^{1}$ Means with the same letters within a species across temperatures are not significantly different at P $\leq 0.05$ according to LSD.

$20^{\circ} \mathrm{C}$ in darkness for pea, radish (Raphanus sativus L.) and kochia; and $15^{\circ} \mathrm{C}$ in darkness for spinach (Spinacia oleracea L.) and big sagebrush (Artemisia tridentata Nutt). Germinated seeds were counted, and seedling axial lengths measured at 3,5, and 7-day intervals for crops; and at 5, 7, 10, 12, and 14 -day intervals for shrubs. We used the maximum seedling axial length to assess seedling vigor (Booth and Griffith 1994). The randomized complete block design (RCBD) was used with 5 replications arranged over time so that no 2 replications of a species were tested simultaneously. Data for each species were analyzed for germination and axial length.

\section{Results and Discussion}

\section{Water Uptake of Seed/Seedling During Imbibition}

The water content of seeds and seedlings after 4 days of incubation ranged from 61 to $1,512 \%$, depending on species and imbibition temperature (Table 2). Many seeds of crops germinated during the 4-day period. This is important since these seeds may have had greater respiration rates than ungerminated seeds. The variation in water content among temperatures was inversely related to seed size. For example, the variation was smaller in species with larger seeds such as sunflower, bean, and pea, than species with smaller seeds. The water uptake for cucumber, sunflower, tomato, and bean seeds increased with increasing imbibition temperatures, while spinach, winter wheat (Triticum aestivum L.), kochia, and big sagebrush seeds imbibed significantly less water at $30^{\circ} \mathrm{C}$ than at lower temperatures.

Seeds generally absorb water more slowly at lower temperatures (Shull 1920, Allerup 1958, Bai et al. 1999), which is attributed to increased viscosity of water with decreasing temperature, and to the effect of temperature on seed membranes (Murphy and Noland 1982,
Vertucci and Leopold 1983, Vertucci 1989). Vertucci (1989) discussed the effect of seed microstructure on water uptake, commenting that temperature was likely to alter that structure. These reports and others (Bewley and Black 1978), discuss imbibition within the context of a linear relationship between increasing temperature and increasing rate of seed moisture uptake. The exceptions to that relationship found in this study, and similar findings by Bai et al. (1997), hint of biochemical differences among seeds with different temperature responses. These differences need to be better understood.

\section{Dry Weight Loss of Seed/Seedling After Imbibition}

Weight losses during imbibition ranged from 0.7 to $50.1 \%$, and generally increased with increasing imbibition temperatures (Table 3). Sunflower showed greater weight loss at 20 than at $30^{\circ} \mathrm{C}$, and bush bean showed no differences among temperatures. We specu-

Table 3. Percent of seed/seedling dry weight loss of 3 shrub and 8 crop species after 4 days of imbibition at various temperatures.

\begin{tabular}{|c|c|c|c|c|c|c|}
\hline \multirow[b]{2}{*}{ Species } & \multicolumn{6}{|c|}{ Imbibition temperature $\left({ }^{\circ} \mathrm{C}\right)$} \\
\hline & 5 & 10 & 15 & 20 & 25 & 30 \\
\hline & \multicolumn{6}{|c|}{ 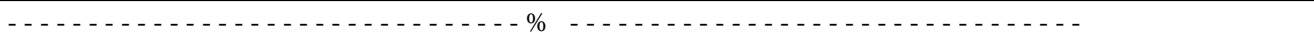 } \\
\hline Grayia spinosa & $24.3 \mathrm{~cd}^{1}$ & $20.8 \mathrm{~d}$ & $18.6 \mathrm{~d}$ & $30.4 \mathrm{bc}$ & $38.5 \mathrm{ab}$ & $43.7 \mathrm{a}$ \\
\hline Kochia prostrata & $8.4 \mathrm{~d}$ & $13.1 \mathrm{~cd}$ & $19.2 \mathrm{c}$ & $28.9 \mathrm{~b}$ & $44.6 \mathrm{a}$ & $50.1 \mathrm{a}$ \\
\hline Artemisia tridentata & 10.7 & - & 13.4 & - & 21.8 & - \\
\hline Cucumis sativus & $1.4 \mathrm{~b}$ & $1.6 \mathrm{~b}$ & $1.9 \mathrm{~b}$ & $2.4 \mathrm{a}$ & $2.3 \mathrm{a}$ & $2.8 \mathrm{a}$ \\
\hline Helianthus annuus & $0.7 \mathrm{c}$ & $1.3 \mathrm{~b}$ & $1.7 \mathrm{ab}$ & $2.2 \mathrm{a}$ & $1.7 \mathrm{ab}$ & $1.6 \mathrm{~b}$ \\
\hline Lycopersicon pimpinellifolium & $2.5 \mathrm{~b}$ & $2.1 \mathrm{~b}$ & $2.6 \mathrm{~b}$ & $1.7 \mathrm{~b}$ & $4.7 \mathrm{a}$ & $5.6 \mathrm{a}$ \\
\hline Phaseolus vulgaris & $1.7 \mathrm{a}$ & $2.5 \mathrm{a}$ & $2.5 \mathrm{a}$ & $4.0 \mathrm{a}$ & $3.6 \mathrm{a}$ & 3. $1 \mathrm{a}$ \\
\hline Pisum sativum & $1.3 \mathrm{de}$ & $2.1 \mathrm{de}$ & $3.6 \mathrm{~d}$ & $5.7 \mathrm{c}$ & $8.4 \mathrm{~b}$ & $10.2 \mathrm{a}$ \\
\hline Raphanus sativus & $0.9 \mathrm{~d}$ & $6.7 \mathrm{bc}$ & $1.6 \mathrm{~d}$ & $3.7 \mathrm{~cd}$ & $7.1 \mathrm{~b}$ & $11.3 \mathrm{a}$ \\
\hline Spinacia oleracea & $3.3 \mathrm{c}$ & $3.9 \mathrm{bc}$ & $4.3 \mathrm{bc}$ & $4.6 \mathrm{~b}$ & $5.6 \mathrm{a}$ & $6.3 \mathrm{a}$ \\
\hline Triticum aestivum & $2.6 \mathrm{~d}$ & $9.3 \mathrm{c}$ & $23.1 \mathrm{~b}$ & $11.4 \mathrm{c}$ & $20.2 \mathrm{~b}$ & $34.0 \mathrm{a}$ \\
\hline
\end{tabular}

${ }_{1}$ Means with the same letters within a species across temperatures are not significantly different at $\mathrm{P} \leq 0.05$ according to LSD. 
Table 4. Germination percentage of 3 shrub and 8 crop species incubated at recommended temperatures.

\begin{tabular}{|c|c|c|c|c|c|c|}
\hline \multirow[b]{2}{*}{ Species } & \multicolumn{5}{|c|}{ Imbibition temperature $\left({ }^{\circ} \mathrm{C}\right)$} & \multirow[b]{2}{*}{30} \\
\hline & 5 & 10 & 15 & 20 & 25 & \\
\hline Grayia spinosa & $16^{1}$ & 29 a & $21 \mathrm{a}$ & $23 \mathrm{a}$ & $25 \mathrm{a}$ & $25 \mathrm{a}$ \\
\hline Artemisia tridentata & $82 \mathrm{a}$ & $73 \mathrm{ab}$ & $80 \mathrm{ab}$ & $82 \mathrm{a}$ & $70 \mathrm{bc}$ & $59 \mathrm{c}$ \\
\hline Cucumis sativus & $92 \mathrm{a}$ & $95 \mathrm{a}$ & $95 \mathrm{a}$ & $98 \mathrm{a}$ & $97 \mathrm{a}$ & $95 \mathrm{a}$ \\
\hline Helianthus аппииs & $94 \mathrm{a}$ & $95 \mathrm{a}$ & $94 \mathrm{a}$ & $94 \mathrm{a}$ & $89 \mathrm{a}$ & $84 \mathrm{a}$ \\
\hline Pisum sativum & $96 \mathrm{a}$ & $98 \mathrm{a}$ & $98 \mathrm{a}$ & $97 \mathrm{a}$ & 99 a & 97 a \\
\hline Raphanus sativus & $100 \mathrm{a}$ & $95 \mathrm{a}$ & $95 \mathrm{a}$ & 99 a & 98 a & $98 \mathrm{a}$ \\
\hline Spinacia oleracea & $76 \mathrm{ab}$ & $74 \mathrm{ab}$ & $82 \mathrm{a}$ & $64 \mathrm{~b}$ & $65 \mathrm{~b}$ & $46 c$ \\
\hline Triticum aestivum & $94 a b$ & $97 \mathrm{a}$ & $98 \mathrm{a}$ & $95 \mathrm{ab}$ & $90 \mathrm{~b}$ & $84 \mathrm{c}$ \\
\hline
\end{tabular}

${ }_{1}^{1}$ Means with the same letters within a species across temperatures are not significantly different at $\mathrm{P} \leq 0.05$ according to LSD.

late that sunflower seeds may have respiration controls that act to conserve food during germination at temperatures higher than optimum for growth, i.e., respiration was inhibited by high temperature. Weight losses were generally smaller for crops than shrubs, except in winter wheat, and larger-seeded species tended to lose relatively less weight than smaller seeded species.

Booth and Haferkamp (1995) reviewed 33 reports published between 1954 and 1988 that correlated seed size (best measured as seed weight) with dicot or monocot seedling vigor. These reports indicate that greater seed size within a species was correlated with greater seedling vigor. Booth (1992) found that post-imbibition dry seed weight was a better predictor of postgermination growth of winterfat than the pre-imbibition seed weight. Because the post-imbibition seed weight is an index of the amount of food remaining for seedling growth after the stressful imbi- bition period, it will be more closely related to post-germination growth than the pre-imbibition seed weight.

\section{Seed Germination as Affected by Imbibition Temperature}

Except for spinach, winter wheat, kochia, and big sagebrush, germination was generally high (>90\%) and was not affected by imbibition temperature (Table 4). Hopsage germination was low and independent of imbibition temperature, possibly due to its low seed viability after a prolonged storage period. Higher temperatures reduced germination for spinach, winter wheat, kochia, and big sagebrush. This may reflect their temperate origins.

\section{Seedling Vigor as Affected by Imbibition Temperature}

Maximum seedling axial length occurred at the end of each experiment
(7 or 14 days) for all temperatures and species except for big sagebrush and hopsage seeds imbibed at $30^{\circ} \mathrm{C}$ (Table 5). Here, maximum length occurred after 10 days of incubation. Post-germination growth increased with increasing imbibition temperature for cucumber and sunflower. It was optimum at 20 and $25^{\circ} \mathrm{C}$ for tomato and bush bean, at $25^{\circ} \mathrm{C}$ for pea, and at 15 to $25^{\circ} \mathrm{C}$ for radish. Low temperatures correlated with greater seedling axial length for winter wheat, hopsage, kochia, and big sagebrush. The benefits of low-temperature imbibition have been previously reported for hopsage (Smith 1974, Shaw et al. 1994) and kochia (Haferkamp et al. 1990).

Seeds with lower weight loss during imbibition had greater post-germination growth, and all crop species, except for winter wheat, fell into this category. Winter wheat had high weight loss as well as high seedling vigor. High weight loss in shrubs was associated with low

Table 5. Maximum average seedling lengths for 3 shrub and 8 crop species after incubation at recommended temperatures.

\begin{tabular}{|c|c|c|c|c|c|c|}
\hline \multirow[b]{2}{*}{ Species } & \multicolumn{6}{|c|}{ Imbibition temperature $\left({ }^{\circ} \mathrm{C}\right)$} \\
\hline & 5 & 10 & 15 & 20 & 25 & 30 \\
\hline Grayia spinosa & $8 b^{1,2}$ & $\underline{13 \mathrm{a}^{3}}$ & $15 \mathrm{a}$ & $7 \mathrm{~b}$ & $8 \mathrm{~b}$ & $5 \mathrm{~b}$ \\
\hline Artemisia tridentata & $\underline{\underline{30 \mathrm{ab}}}$ & $\overline{31 \mathrm{a}}$ & $27 \mathrm{ab}$ & $\overline{26 b}$ & $21 \mathrm{ce}$ & $20 \mathrm{~d}$ \\
\hline Cucumis sativus & $1 \overline{78 d}$ & $\overline{195 \mathrm{c}}$ & $\overline{205 c}$ & $263 \mathrm{~b}$ & $271 \mathrm{~b}$ & $\underline{291 \mathrm{a}}$ \\
\hline Helianthus annuиs & $227 \mathrm{c}$ & $281 \mathrm{~b}$ & $290 \mathrm{~b}$ & $\underline{399 \mathrm{a}}$ & $\underline{361 \mathrm{a}}$ & $\underline{341 \mathrm{a}}$ \\
\hline Pisum sativum & $239 \mathrm{e}$ & $265 \mathrm{~d}$ & $291 \mathrm{c}$ & $\overline{288 b}$ & $\overline{316 a}$ & $293 \mathrm{~b}$ \\
\hline Raphanus sativus & $260 d$ & $287 \mathrm{bc}$ & $\underline{301 \mathrm{ab}}$ & $\underline{318 \mathrm{a}}$ & $\underline{304 \mathrm{ab}}$ & $273 \mathrm{c}$ \\
\hline Spinacia oleracea & $\underline{112 \mathrm{ab}}$ & $\underline{119 \mathrm{a}}$ & $\underline{115 \mathrm{ab}}$ & $97 \mathrm{~b}$ & $\underline{105 \mathrm{ab}}$ & $60 \mathrm{c}$ \\
\hline Triticum aestivum & $\underline{336 \mathrm{a}}$ & $\overline{292 b}$ & $\overline{263 \mathrm{bc}}$ & $253 \mathrm{~cd}$ & $\overline{227 \mathrm{~d}}$ & $222 \mathrm{~d}$ \\
\hline
\end{tabular}

Maximum seedling length was reached after 7 days of incubation for crops and after 14 days of incubation for shrubs, except for Grayia spinosa and Artemisia tridenta which when imbibed at $30^{\circ} \mathrm{C}$, reached maximum seedling length after 10 days of incubation.

${ }^{2}$ Means with the same letters within a species across temperatures are not significantly different at $\mathrm{P} \leq 0.05$ according to LSD.

${ }^{3}$ Underline indicates values that are not different from maximum. 
seedling vigor. These results are evidence that imbibition temperature influences (1) moisture uptake, (2) seed weight loss during imbibition, (3) germination, and (4) seedling vigor.

Recent work in our laboratory has found that the age of winterfat seeds influences the vigor response to imbibition temperature (Booth et al. 1999). This raises the question of the effect of age on studies reported here. Since there are differences among species from equal-age seed, such as among cucumber, tomato, and spinach (Table 5), we suspect that species, age, and environment interact to define a vigor response to imbibition temperature.

We tested one seed lot for each of 11 species to assess general, rather than specific, responses. Our results suggest species differences, but do not define specific imbibition temperature responses. Our results do establish that there is a continuum in vigor responses to imbibition temperatures for a wide variety of seeds (Tables 2 and 5). Previous work has focused on chilling injury in plants of tropical or subtropical origins. We have shown an effect of imbibition temperature for those species, and for plants of temperate origin. The significance of these ecophysiological interactions on the dynamics of temperate plant populations in agronomic and wildland settings needs to be understood.

We conclude that seed -testing personnel seeking to measure full expression of seed growth potential must give attention to imbibition temperature as a distinct part of the germination protocol. We recommend that guidelines be developed for imbibing seeds and that these be incorporated into seed testing procedures recommended by the Association of Official Seed Analysts (AOSA), International Seed Testing Association (ISTA), similar organizations, and in published guidelines such as Agricultural Handbook 450 (Schopmeyer 1974). Perspectives in seed science and technology have been strongly influenced by crop species with long agronomic histories. This study has revealed differences in seed response to temperature for a wide variety of seeds. That information should broaden our perspective of seed testing, particularly as more and more rangeland plants come into the seed trade.

\section{Literature Cited}

Allerup, S. 1958 Effect of temperature on uptake of water in seeds. Plant Physiol. 11:99-105.

Association of Official Seed Analysts. 1988. Rules for testing seeds (Revised 1989, 1990). J. Seed Technol. 12:1-109.

Bai, Y., D.T. Booth, and J.T. Romo. 1999. Imbibition temperature affects winterfat (Eurotia lanata (Pursh) Moq.) seed hydration and cold-hardiness response. J. Range Manage. 52: 271-274.

Bai, Y., D.T. Booth, and E.E. Roos. 1997. Effect of seed moisture on Wyoming big sagebrush seed quality. J. Range Manage. 50:419-422.

Bewley, J.D. and M. Black. 1978. Physiology and biochemistry of seeds. Vol. I. Springer Verlag, New York.

Booth, D.T. 1992. Seedbed ecology of winterfat: Imbibition temperature affects post germination growth. J. Range Manage. 45:15-164.

Booth, D.T. and L.W. Griffith. 1994. Measuring post -germination growth. J. Range Manage. 47:503-504.

Booth, D.T. and M.R. Haferkamp. 1995. Morphology and seedling establishment. pp. 239-290. In: D.J. Bedunah and R.E. Sosebee (eds.), Wildland plants: Physiological ecology and development morphology. Soc. Range Manage., Denver, Colo.

Booth, D.T., R. Agustrina, and R.H. Abernethy. 1999. Evidence of cell deterioration in winterfat seeds during refrigerated storage. J. Range Manage. 52:290-29.

Bradford, K.J. 1995. Water relations in seed germination. pp. 351-396. In: J. Kigel and G. Galili (eds.), Seed development and germination. Marcel Dekker, New York.

Haferkamp, M.R., D.C. Ganskopp, K.L. Marietta, and B.W. Knapp. 1990. Environmental influences on germination of utricles and seedling establishment of "Immigrant" forage. J. Range Manage. 43:518-522.

Highkin, H.R. and A. Lang. 1966. Residual effect of germination temperature on the growth of peas. Planta 68:94 -98.

Jennings, P. and M.E. Saltveit. 1994. Temperature effects on imbibition and germination of cucumber (Cucumis sativus) seeds. J. Amer. Soc. Hort. Sci. 119:464-467.

Jones, L.G. and R.D. Cobb. 1963. A technique for increasing the speed of laboratory germination testing. Proc. Assoc. Official Seed Anal. 53:144-160.

Justice, O.L. and L.N. Bass. 1978. Principles and practices of seed storage. Agr. Handb. No. 506. USDA Science and Education Admin., U.S. Gov. Printing Office, Washington, D.C.

Lyons, J.M. 1973. Chilling injury in plants. Annu. Rev. Plant Physiol. 24:445-466.

Murphy, J.B. and T.L. Noland. 1982.
Temperature effects on seed imbibition and leakage mediated by viscosity and membranes. Plant Physiol. 69:428-435.

Pollock, B.M. 1969. Imbibition temperature sensitivity of lima bean seeds controlled by initial seed moisture. Plant Physiol. 44:907-911.

Pollock, B.M., E.E. Roos, and J.R. Manalo. 1969. Vigor of garden bean seeds and seedlings influenced by initial seed moisture, substrate oxygen, and imbibition temperature. J. Amer. Soc. Hort. Sci. 94:577-584.

Roos, E.E., J.R. Manalo, and B.M. Pollock. 1976. Effect of initial seed moisture on snap bean emergence from cold soil. J. Amer. Soc. Hort. Sci. 101:321-324

Schopmeyer, C.S. 1974. Seeds of woody plants in the United States. Agr. Handb. No 450. USDA Forest Service, U.S. Gov. Printing Office, Washington, D.C.

Segeta, V. and E. Tronickova. 1966. Ecology and physiology of the resistance to the cold of germinating cucumbers. II. Physiological reactions of seeds and seedlings 